\title{
PENGARUH MEDIA KOTAK KARTU MISTERIUS (KOKAMI) TERHADAP HASIL BELAJAR SISWA PADA MATERI POKOK HUKUM-HUKUM DASAR KIMIA DI SMA NEGERI 12 BANJARMASIN
}

\author{
The Influence of Misterious Card Box (KOKAMI) To Student's \\ Learning Outcomes On Basic Chemical Laws Material In SMA Negeri 12 \\ Banjarmasin
}

Ika Agustina Wulandari, Mohan Taufiq Mashuri, Novrian Dony Program Studi Pendidikan Kimia Fakultas Keguruan dan Ilmu Pendidikan Universitas Islam Kalimantan Muhammad Arsyad Al Banjari, Banjarmasin *e-mail: ikaagustinawulandari17@gmail.com

\begin{abstract}
Abstrak.Penelitian ini bertujuan untuk mengetahui pengaruh media kotak kartu misterius (kokami) terhadap hasil belajar siswa pada materi pokok hukum-hukum dasar kimia di SMA Negeri 12 Banjarmasin. Metode penelitian ini adalah metode kuantitatif yang menggunakan jenis penelitian quasi eksperiment dan desain penelitian nonequivalent control group design. Penelitian ini dilakukan dengan tiga langkah yaitu: Pretest, Perlakuan, dan Posttest. Sampel dalam penelitian ini adalah siswa kelas X Mia 2 dan X Mia 3. Pengumpulan data dilakukan dengan menggunakan tes, dokumentasi dan wawancara. Instrumen penelitian ini menggunakan soal pilihan ganda dan foto. Berdasarkan hasil analisis data menggunakan uji Mann-Whitney didapatkan $Z_{\text {hitung }}$ bernilai $-1,05$ dan $Z_{\text {tabel }}$ bernilai 1,96 pada taraf signifikan $5 \%$. Jika $Z_{\text {hitung }}<-Z_{\text {tabel }}$ maka $\mathrm{H}_{0}$ ditolak, ternyata $-1,05<$ $-1,96$ maka $\mathrm{H}_{0}$ ditolak dan $\mathrm{H}_{\mathrm{a}}$ diterima, maka dapat disimpulkan bahwa terdapat pengaruh dalam penggunaan media kotak kartu misterius (kokami) dalam meningkatkan hasil belajar siswa pada materi pokok hukum-hukum dasar kimia di SMA Negeri 12 Banjarmasin.
\end{abstract}

Kata Kunci: Kotak Kartu Misterius, Hasil Belajar, Hukum-Hukum Dasar Kimia

Abstract. The purpose of this research is to find out the influence of media kokami or misterious card box against students' learning achievement on material of the basic laws in chemistry at Public Senior High School 12 Banjarmasin. Method which used quasi experiment research type and for the design of the research is non equivalentcontrol group design. This research cloncludes in three steps which are pretest, treatment, and posttest. The sample of this research is students from grade X Mia 2 and Mia 3. The data collection technique used test, documentation, and interview. The used research instrument is multiple choice and photographs. Based on the result of data analysis using Mann-Whithney test gained $Z_{\text {count }}$ is $-1,05$ and $Z_{\text {table }}$ is 1,96 at $5 \%$ level of significance. If $Z_{\text {count }}<-Z_{\text {table }}$ , so $H_{0}$ is denied. Furthermore -1,05 <-1,96 so $H_{0}$ is denied and $H_{a}$ is accepted. It can concluded that there is influence from using kokami or misterious card box to increase students' learning achievement on material of the basic lawsin chemistry at Public Senior High School 12 Banjarmasin.

Keywords: Misterious Card Box, Learning Outcomes, Basic Chemical Laws 


\section{PENDAHULUAN}

Pendidikan adalah proses perubahan atau pendewasaan manusia, berawal dari tidak tahu menjadi tahu, dari tidak bisa menjadi bisa, dari tidak paham menjadi paham dan sebagainya. Dalam Undang-Undang RI Nomor 20 Tahun 2003 tentang Sistem Pendidikan Nasional pasal 1 ayat 1, menyebutkan bahwa : Pendidikan adalah usaha sadar dan terencana untuk mewujudkan suasana belajar dan proses pembelajaran agar peserta didik secara aktif mengembangkan potensi dirinya untuk memiliki kekuatan spiritual keagamaan, pengendalian diri, kepribadian, kecerdasan, akhlak mulia serta keterampilan yang diperlukan dirinya, masyarakat, bangsa dan negara (Hasbullah, 2013). Agar dapat menciptakan proses pendidikan yang baik, bermula dari propesional pembelajaran yang dilakukan oleh guru.

Untuk saat ini sering kali proses pembelajaran lebih didominasi oleh guru sehingga respon siswa sangat minim dan pasif dalam mengikuti pembelajaran. Kondisi tersebut sering terjadi dalam pembelajaran kimia karena kebanyakan siswa menganggap materi pembelajaran kimia sangat sulit, membosankan dan tidak menyenangkan. Dalam kondisi pembelajaran yang seperti ini siswa merasa seolah-olah dipaksa untuk belajar sehingga dapat membuat jiwanya tertekan. Hal seperti inilah yang dapat membuat hasil belajar siswa menjadi rendah. Maka diperlukannya proses pembelajaran yang efektif yang dapat menarik perhatian siswa untuk belajar dan membuat siswa aktif dalam proses pembelajaran. Salah satu cara yang dapat digunakan untuk saat ini penggunaan metode atau media pembelajaran.

Berdasarkan hasil wawancara dengan guru mata pelajaran kimia di SMA Negeri 12 Banjarmasin, permasalahan yang sering dihadapi dalam pembelajaran kimia adalah pada saat proses pembelajaran berlangsung guru harus menyampaikan materi pembelajaran secara berulang dan lebih intens hal tersebut disebabkan karena mata pelajaran kimia adalah mata pelajaran baru dan mereka baru mendapatkan dijenjang sekolah menengah atas, sehingga ada beberapa kelompok siswa yang masih kesusahan atau kebingungan dalam memahami materi yang disampaikan, meskipun demikian hasil belajar siswa pada ujian tengah semester ganjil 2017/2018 cukup baik karena banyak siswa yang nilainya mencapai KKM yang sudah ditentukan sekolah. Namun tetap harus diadakan variasi terhadap media ataupun model pada saat pembelajaran agar dapat membuat siswa lebih bersemangat dan tidak menjadi pasif, sehingga dapat meningkatkan hasil belajar yang lebih baik dari sebelumnya.

Salah satu materi pembelajaran kimia yang dianggap sulit oleh siswa adalah materi hukum-hukum dasar kimia. Materi hukum-hukum dasar kimia merupakan materi yang mempunyai karakteristik yaitu bersifat kongkrit sampai yang bersifat abstrak, bersifat rill dan dekat dengan kehidupan sehari-hari maka perlu menggabungkan antara pemahaman konsep dan aplikasi, membutuhkan kemampuan matematika yang baik dan membutuhkan pemahaman konsep yang baik dan nalar logika yang tinggi dalam penyelesaian soal-soalnya.Adapun media yang dapat digunakan untuk mengatasi permasalahan diatas adalah Kokami (Kotak dan kartu misterius) merupakan salah satu jenis media yang dikombinasikan dengan permainan bahasa (Kadir, 2004) dalam (Rusiana, 2014). Permainan ini menjadi salah satu alternatif, selain untuk menanamkan pengetahuan kepada siswa dengan menarik dan berbekas juga berfungsi untuk merangsang minat dan perhatian siswa. Guru sebagai sebagai instruktur sekaligus fasilitator menyiapkan sebuah kotak yang didalamnya berisi pesan-pesan dan pesan itu 
dapat berupa perintah, gambar, pertanyaan dan sanksi yang ditulis diatas potonganpotongan karton yang dimaksukkan kedalam amplop tertutup. Kartu pesan ini merupakan komponen yang paling penting dalam permainan ini karena arah kegiatan belajar mengajar tertuang didalamnya.

Berdasarkan hasil penelitian dari (Wirda dkk, 2016) menyimpulkan bahwa penggunaan media pembelajaran kotak kartu misterius (KOKAMI) dapat meningkatkan aktivitas dan ketuntasan belajar siswa pada pokok bahasan hidrokarbon dan minyak bumi di kelas X.8 SMAN 9 Pekanbaru. Hal ini terlihat peningkatan aktivitas belajar siswa dari $72,53 \%$ pada siklus I menjadi $88,81 \%$ pada siklus II, dan ketuntasan belajar dari $89,47 \%$ pada siklus I menjadi $100 \%$ pada siklus II. Maka tidak menutup kemungkinan penggunaan media kotak kartu misterius pada materi hukum-hukum dasar kimia di SMA Negeri 12 Banjarmasin dapat berpengaruh terhadap hasil belajar siswa kelas X. Dengan demikian peneliti tertarik untuk melakukan penelitian yang berjudul "Pengaruh Media Kotak Kartu Misterius (KOKAMI) Terhadap Hasil Belajar Siswa pada Materi Pokok Hukum-hukum Dasar Kimia di SMA Negeri 12 Banjarmasin”.

\section{METODE PENELITIAN}

Penelitian ini adalah penelitian kuantitatif dengan jenis penelitian eksperimen semu (Quasi-experimental) dan menggunakan desain penelitian Nonequivalent Control Group Design. Dimana masing-masing kelas akan diberikan Pretest terlebih dahulu untuk mengetahui kemampuan awalnya, baru kemudian pada kelas eksperimen diberikan perlakuan berupa permainan media kokami dan pada kelas kontrol tidak diberikan perlakuan, lalu masing-masing kelas diberikan Posttest untuk mengetahui hasil belajarnya. Penelitian ini telahdilaksanakan di SMA Negeri 12 Banjarmasin. Waktu dilaksanakan penelitian yaitu pada bulan April s.d Mei 2018. Populasi dalam penelitian ini adalah seluruh siswa kelas X Mia di SMA Negeri 12 Banjarmasin tahun ajaran 2017/2018 dengan jumlah siswa sebanyak 71 siswa. Sampel yang diambil dalam penelitian ini adalah siswa kelas X Mia 2 dengan jumlah siswa 24 dan X Mia 3 dengan jumlah siswa 24. Dimana kelas X Mia 2 dijadikan sebagai kelas kontrol dan kelas X Mia 3 dijadikan sebagai kelas Eksperimen (Sugiyono, 2015).

Teknik pengumpulan data yangdigunakan dalam penelitian ini adalah teknik tes, dokumentasi dan wawancara. Sedangkan instrumen pengumpulan datanya menggunakan lembar soal pilihan ganda dan foto. Dalam Analisis hasil uji coba instrumen menggunakan uji validitas instrumen, uji reliabilitas instrumen, uji taraf kesukaran instrumen dan uji daya pembeda instrumen. Dalam uji validitas instrumen menggunakan validitas isi dan validitas butir soal (Arikunto, 2016). Sedangkan dalam analisis data penelitian menggunakan uji normalitas dan uji hipotesis. Dalam uji normalitas menggunakan uji liliefors (Sudjana, 2005). Sedangkan dalam uji hipotesis menggunakan uji mann-whithney (Syofian, 2013).

\section{HASIL DAN PEMBAHASAN}

Penelitian pengaruh media kotak kartu misterius (KOKAMI) terhadap hasil belajar siswa pada materi pokok hukum-hukum dasar kimia di SMA Negeri 12 Banjarmasin telah dilaksanakan pada semester genap tahun ajaran 2017/2018. Penelitian ini dilaksanakan pada bulan april s.d mei 2018. Pada tahap analisis instrumen dilakukan uji coba instrumen yang di nilai oleh 3 orang validator ahli dan 24 siswa. 
Penelitian ini dilakukan dengan menggunakan desain Nonequivalent control group design. Dalam desain ini terdapat dua kelompok subjek yang mana satu kelompok eksperimen (diberi perlakuan) dan kelompok kontrol (tidak diberi perlakuan). Data awal penelitian didapatkan dari hasil Pretest yakni dengan tes dan diberikan sebelum perlakuan diberikan. Dan data akhir penelitian didapatkan dari Posttest yang diberikan setelah pemberian perlakuan dengan menggunakan media kotak kartu misteriusuntuk kelas eksperimen dan konvensional pada kelas kontrol. Berikut adalah rata-rata nilai Pretest dan Posttest pada kelas kontrol dan eksperimen.

Tabel 1. Hasil rata-rata Pretest dan Posttest

\begin{tabular}{ccc}
\hline Kelas & Pretest & Posttest \\
\hline Kontrol & 22,84 & 62,49 \\
Eksperimen & 21,65 & 62,5 \\
\hline
\end{tabular}

Dari tabel diatas, dapat diketahui bahwa terdapat kenaikan rata-rata pada kelas kontrol maupun kelas eksperimen. Pada kelas kontrol kenaikan rata-rata terlihat dari 22,84 menjadi 62,49 sedangkan pada kelas eksperimen kenaikannya rata-ratanya dari 21,65 menjadi 62,5. Dapat dilihat dari rata-rata kenaikan hasil Posttest pada kelas kontrol dan eksperimen berbeda dimana pada kelas eksperimen mengalami kenaikan lebih besar dibandingkan kelas kontrol. Untuk lebih mengetahui apakah terjadi kenaikan yang signifikan maka perlu dilakukan uji hipotesis. Sebelum dilakukan uji hipotesis maka dilakukan uji prasyarat terlebih dahulu. Uji prasyarat yang dilakukan adalah uji normalitas dan uji homogenitas. Pada uji normalitas digunakan uji liliefors dengan perhitungan manual.

Berdasarkan tabel hasil uji normalitas Posttest didapatkan pada kelas kontrol nilai $\mathrm{L}_{0}>\mathrm{L}_{\text {tabel }}$ yang artinya data tidak terdistribusi normal sama halnya pada kelas eksperimen didapatkan nilai $\mathrm{L}_{0}>\mathrm{L}_{\text {tabel }}$ yang artinya data tidak terdistribusi normal. Karena data yang didapatkan dari hasil uji normalitas tidak terdistribusi normal pada kedua kelas maka tidak bisa dilakukan uji hipotesis. Jadi tahap selanjutnya untuk mnegetahui uji beda dua rata-rata untuk data posttest dari kedua kelas langsung menggunakan uji Mann-Whithneysebagai uji hipotesis. Uji Mann-Whithney adalah uji nonparametris yang digunakan untuk mengetahui perbedaan media kedua kelompok bebas apabila skala data variabel terikatnya adalah ordinal atau interval/ratio tetapi tidak terdistribusi normal.

Dari hasil uji Mann-Whithney yang telah dilakukan didapatkan nilai $\alpha=5 \%$ dengan nilai $Z_{\text {tabel }}=0,957$. Nilai 0,957 pada tabel distribusi normal adalah 1,96 sedangkan nilai $Z_{\text {hitung }}$ adalah $-1,05$. Jika $Z_{\text {hitung }}<-Z_{\text {tabel }}$, maka $\mathrm{H}_{0}$ ditolak. Ternyata $-1,05$ $<-1,96$ maka $\mathrm{H}_{0}$ ditolak. Sehingga dapat disimpulkan bahwa dari penelitian yang telah dilaksanakan terdapat perbedaan yang signifikan terhadap kedua kelas tersebut artinya $\mathrm{H}_{0}$ ditolak dan $\mathrm{H}_{\mathrm{a}}$ diterima, perbedaan tersebut terjadi akibat adanya perlakuan yang berbeda diantara kedua kelas tersebut. Berdasarkan kesimpulan diatas maka dapat dikatakan bahwa penelitian yang telah dilaksankan menggunkan media kotak kartu misterius (KOKAMI) berhasil meningkatkan hasil belajar siswa pada materi hukumhukum dasar kimia pada siswa kelas X Mia di SMA Negeri 12 Banjarmasin.

Hasil penelitian ini hanya terfokus pada hasil belajar siswa. Hasil belajar yang diharapkan dapat tercapai pada penelitian ini adalah hasil penelitian dalam ranah 
pengetahuan, pemahaman dan penerapan. Dengan adanya penelitian ini diharapkan siswa dapat menjadi lebih aktif dalam proses pembelajaran. Penggunaan media pembelajaran terbukti dapat menghasilkan respon yang baik. Respon yang dimaksud adalah hasil belajar yang telah tercapai. Hasil belajar pada kelas kontrol yang tidak menggunakan media dan pada kelas eksperimen yang menggunakan media kotak kartu misterius memiliki perbedaan.

Berdasarkan hasil analisis data hasil belajar siswa kelas X Mia 2 dan X Mia 3 di SMA Negeri 12 Banjarmasin, maka hipotesis $\mathrm{H}_{\mathrm{a}}$ yang dikemukakan dalam bab II, yaitu "Terdapat pengaruh media kotak kartu misterius (KOKAMI) terhadap hasil belajar materi hukum-hukum dasar kimia pada siswa kelas X SMA Negeri 12 Banjarmasin" dapat diterima. Hal tersebut dikarenakan media kotak kartu misterius (KOKAMI) dapat memberikan dampak positif terhadap hasil belajar. Pernyataan tersebut dapat dilihat dari hasil uji Mann-Whithney.

\section{PENUTUP}

Berdasarkan hasil penelitian dan pembahasan yang telah dipaparkan maka dapat diambil kesimpulan bahwa dalam hasil analisis data menggunakan uji Mann-Whithney didapatkan $Z_{\text {hitung }}$ bernilai $-1,05$ dan $Z_{\text {tabel }}$ bernilai 1,96 pada taraf signifikan 5\%. Jika $\mathrm{Z}_{\text {hitung }}<-\mathrm{Z}_{\text {tabel }}$ maka $\mathrm{H}_{0}$ ditolak dan $\mathrm{H}_{1}$ diterima, maka dapat disimpulkan bahwa terdapat pengaruh dalam penggunaan media kotak kartu misterius dalam meningkatkan hasil belajar siswa pada materi pokok hukum-hukum dasar kimia di SMA Negeri 12 Banjarmasin

\section{DAFTAR RUJUKAN}

Arikunto, S. (2016). Dasar-dasar Evaluasi Pendidikan. Jakarta: Bumi Aksara.

Hasbullah. (2013). Dasar-dasar Ilmu Pendidikan (Umum dan Agama Islam). Jakarta: Rajawali pers.

Siregar, S. (2013). Metode Penelitian Kuantitatif. Jakarta: Parenada Media Grup.

Sudjana. (2015). Metoda Statistik. Jakarta:Tarsito.

Sugiyono. (2015). Metode Penelitian Pendidikan: Pendekatan Kuantitatif, Kualitatif, dan $R \& D$. Bandung: Alfabeta.

Wirda, NN., Susilawati., Hariyati, S. (2016). Penggunaan Media Pembelajaran Kotak dan Kartu Misterius (KOKAMI) untuk Meningkatkan Aktifitas dan Ketuntasan Belajar Siswa pada Pokok Bahasan Hidrokarbon dan Minyak Bumi dikelas X.8 SMAN 9 Pekanbaru.

Rusiana, Y. (2014). Penggunaan Media KOKAMI pada Mata Pelajaran IPA untuk Meningkatkan Hasil Belajar Siswa Kelas VA SDN Darungan 01 Kecamatan Tanggul Kabupaten Jember. Pancaran, 3(4), 183-192. 